\title{
Religion, Schools, and Judicial Decision Making: An Empirical Perspective
}

\author{
Michael Heise $\dagger \&$ Gregory C. Sisk $\dagger \dagger$
}

\section{INTRODUCTION}

From the beginning of modern religious-liberty jurisprudence, the most difficult and penetrating questions about the proper relationship between church and state have arisen with special frequency, controversy, and fervor in the often-charged atmosphere of education. As Professor Joseph Viteritti notes, "As far back as can be remembered, religion has been at the center of American education, as a source of both inspiration and agitation."' Likewise, Professor Thomas Berg observes that "religion and education are perennially mixing." When reviewing the battles about when the state must accommodate the religious demands of individual citizens and how the government should balance recognition of religious traditions in American history against the prohibition on government endorsement of religion, we find that school boards, school administrators, teachers, students, and their parents have often occupied the front lines. ${ }^{3}$

Schools and the religion clauses collide persistently, and litigation frames many of these collisions. Current collisions rest on a deep legal history and approaches to resolving them continue to evolve over time. Indeed, the Supreme Court's first encounters with

$\dagger$ Professor, Cornell Law School.

$\dagger \dagger$ Laghi Distinguished Chair in Law, University of St. Thomas School of Law.

We thank Dawn M. Chutkow as well as participants in the Understanding Education in the United States Symposium at the University of Chicago Law School for comments on an earlier draft. Professor Sisk offers thanks to his assistant, Bethany Fletcher, for recording data coding and to law students Eric Beecher and Alicia Long for assistance with opinion coding. A spreadsheet containing our data set, regression run results, coding of each decision, coding of each judge, and code books may be found at http://courseweb.stthomas.edu/gcsisk /religion.study.data/cover.html.

1 Joseph P. Viteritti, The Last Freedom: Religion from the Public School to the Public Square 74 (Princeton 2007).

2 Thomas C. Berg, The Story of the School Prayer Decisions: Civil Religion under Assault, in Richard W. Garnett and Andrew Koppelman, eds, First Amendment Stories 193, 194 (West 2011).

3 See Viteritti, The Last Freedom at 204-05 (cited in note 1). 
both of the religion clauses of the First Amendment in the modern era were in the education context. In 1925, in what later came to be recognized as the first application of the Free Exercise of Religion Clause of the First Amendment against the states, the Supreme Court held in Pierce $v$ Society of Sisters ${ }^{4}$ that Oregon could not mandate that all children attend public schools and override a religiously motivated parental preference to send their children to religious schools. ${ }^{5}$ Many decades later, in Employment Division $v$ Smith, ${ }^{6}$ the Court described Pierce as an example of the "Free Exercise Clause [working] in conjunction with other constitutional protections," specifically, "the right of parents... to direct the education of their children." In 1947, in Everson $v$ Board of Education, the Supreme Court first applied the Establishment Clause against the states, turning away a challenge to the use of public funds to reimburse parochial school students for bus transportation. ${ }^{9}$ And, in a landmark decision that continues to invite contest a half century later, the Supreme Court's Engel v Vitale decision in 1962 ended officially sponsored prayer in public schools."

Educational policy makers' interest in nonpublic schools, including religious schools, is long standing and flows from at least two prominent sources. One source involves private schools' record of addressing their students' educational needs. The modern scholarly effort to assess the educational efficacy of public and private schools was launched largely by the groundbreaking research of Professor James Coleman and various colleagues at the University of Chicago and focused on studies of Catholic schools. ${ }^{12}$ A second,

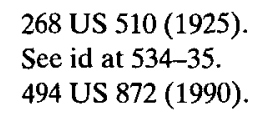

Id at 881. See also Wisconsin v Yoder, 406 US 205, 233 (1972) ("[T]he Court's holding in Pierce stands as a charter of the rights of parents to direct the religious upbringing of their children."); Troxel v Granville, 530 US 57, 95 (2000) (Kennedy dissenting) (observing that if Pierce had "been decided in recent times," it might "well have been grounded upon First Amendment principles protecting freedom of speech, belief, and religion").

8330 US 1 (1947).

9 See id at 15 .

10370 US 421 (1962)

11 See id at 422-25.

12 See James S. Coleman, Thomas Hoffer, and Sally Kilgore, High School Achievement: Public, Catholic, and Private Schools Compared 143-46 (Basic Books 1982) (noting the distribution of academic success across various student backgrounds in Catholic schools); Andrew M. Greeley, Catholic High Schools and Minority Students 96-98 (Transaction 2002). For a more recent summary of the relevant literature, see Timothy Walch, Parish School: American Catholic Parochial Education from Colonial Times to the Present 249-61 (Crossroad 1996). For more recent studies on the "Catholic School Effect," see Derek Neal, The Effects of Catholic Secondary Schooling on Educational Achievement, 15 J Labor Econ 98, 99-100 (1997). 
more recent, and newly emerging source involves nonpublic schools' ability to generate important positive externalities for the communities surrounding these schools. ${ }^{13}$

As various school reform initiatives increasingly seek to leverage private and religious schools in the service of improving education, the number and magnitude of legal collisions involving the religion clauses increase. ${ }^{4}$ Publicly funded voucher programs, for example, are among the most visible (and recent) of such educationreform initiatives. Inevitably, such school reform initiatives triggered litigation. While the Supreme Court resolved a critical Establishment Clause question arising from the public funding of a voucher program that included substantial religious school participation in 2002 in Zelman v Simmons-Harris, ${ }^{15}$ derivative litigation persists. ${ }^{16}$

Indeed, last term the Supreme Court once again waded into turbulent religion clauses waters when it deflected challenges to an Arizona statewide scholarship-tax-credit program in Arizona Christian School Tuition Organization $v$ Winn. ${ }^{17}$ Under the Arizona program, citizens who donate to qualifying nonprofit organizations are entitled to take a dollar-for-dollar tax credit against their state taxes - up to $\$ 500$ per taxpayer. ${ }^{18}$ Recipient nonprofit organizations include religious elementary and secondary schools. The Court's 5-4 decision, reversing the Ninth Circuit, concluded that Arizona taxpayers lack standing to challenge the provision of tax credits for contributions to organizations that subsidize tuition at private religious schools. ${ }^{19}$ Justice Anthony Kennedy, writing for the majority, argued that the taxpayers could not avail themselves of the narrow exception to the general rule against taxpayer standing created by Flast $v$ Cohen. ${ }^{20}$ Echoing a theme from Zelman, the Court's decision in Winn emphasizes that any funding to religious

13 See Margaret F. Brinig and Nicole Stelle Garnett, Catholic Schools, Urban Neighborhoods, and Education Reform, 85 Notre Dame L Rev 887, 921 (2010) (finding that Catholic school closures increase social disorder in surrounding neighborhoods).

14 See Note, Church, Choice, and Charters: A New Wrinkle for Public Education?, 122 Harv L Rev 1750, 1751 (2009) (discussing "religiously themed" public charter schools).

15536 US 639 (2002).

16 See, for example, Eulitt v Maine, Department of Education, 386 F3d 344, 348-49 (1st Cir 2004) (considering whether the First Circuit's leading precedent on questions related to the public funding of religious schools was still consistent with the Establishment Clause after Zelman).

$17131 \mathrm{~S} \mathrm{Ct} 1436$ (2011).

18 See id at 1440.

19 See id at 1447.

20 See id at 1445-49, citing Flast $v$ Cohen, 392 US 83, 102-06 (1968). 
schools was a function of private taxpayer action rather than state activity. ${ }^{21}$

While voucher programs certainly garner substantial public attention, such programs do not fully describe the breadth of the intersections among public schools, religion, education reform, and religious schools. For example, many public school districts have recently become far more amenable to introducing religious subjects into the formal school curriculum..$^{22}$ Additionally, one aspect of the No Child Left Behind Act, ${ }^{23}$ easily the federal government's most significant foray into the nation's elementary and secondary schools, ${ }^{24}$ that has generated relatively little public discussion is how the law facilitates public financial support for religious faith-based groups that provide tutoring services to students who qualify for such supplemental services, so long as the services provided are secular. ${ }^{25}$

That various education-reform initiatives continue to implicate religious schools, the Court's evolving religion clause jurisprudence, and the particular application of the religion clauses in the education setting underscore the need to gain a clearer understanding of how federal courts resolve such claims. While scholars approach such questions from an array of perspectives, ours is empirical and focuses on various background factors that are thought to inform religionclauses-litigation outcomes that involve elementary and secondary schools. Although different models seek to structure the relation between schools and the First Amendment in different ways, in this Article we dwell on one such model that we have considered previously, the "proreligion" model. ${ }^{26}$

Partly owing to the Supreme Court's use of malleable balancing tests and open-ended exceptions, the religion clauses doctrine is noted for instability and uncertainty. ${ }^{27}$ Doctrinal instability and uncertainty affords lower federal court judges ample space to exercise their judgment and discretion in resolving religious cases.

21 See Winn, $131 \mathrm{~S} \mathrm{Ct}$ at 1447.

22 See Viteritti, The Last Freedom at 228 (cited in note 1).

23 Pub L No 107-110, 115 Stat 1425 (2002), codified in various sections of Title 20.

24 For a general discussion of the No Child Left Behind Act, see James E. Ryan, The Perverse Incentives of the No Child Left Behind Act, 79 NYU L Rev 932, 939-44, 987-89 (2004).

25 See 20 USC $\$ 6316$ (e)(5)(D). For further commentary on the "supplemental services" provision and the constitutional implications of funding faith-based organizations through the No Child Left Behind Act, see William Dolan, No Child Left Behind's Faith-Based Initiative Provision and the Establishment Clause, 33 J L \& Educ 1, 5 (2004).

26 For a fuller articulation of the proreligion/accommodationist model, see Gregory C. Sisk, Michael Heise, and Andrew P. Morriss, Searching for the Soul of Judicial Decisionmaking: An Empirical Study of Religious Freedom Decisions, 65 Ohio St L J 491, 504-08 (2004).

27 See id at $497 \&$ n 10. 
Insofar as our school cases overlay a frequently highly charged political context-elementary and secondary education-on to religious issues, the prospect for extrajudicial factors to influence judicial outcomes increases. ${ }^{28}$ One benefit for empiricists, then, is that precisely because lower federal court judges are not typically bound by determinate high-court precedent, a study, such as ours, of factors that influence judicial decisions in this area is likely to bear fruit. ${ }^{29}$

Incident to our larger, ongoing empirical examination of religious-liberty decisions in the lower federal courts, ${ }^{30}$ this Article examines the efficacy of the proreligion model in the education setting. To do so, we studied all digested Establishment and Free Exercise Clause decisions by federal court of appeals and district court judges from 1996 through 2005 that involved elementary and secondary schools. As it relates to differences between school and other (or nonschool) cases, what we find, in brief, is that our alternative ideology variables of party of appointing President and common space scores achieve significance. ${ }^{31}$ That is, while Republican-appointed judges were more likely than their Democratic-appointed counterparts to reach a proreligion decision in school cases, ideology did not correlate with a proreligion outcome in nonschool cases. Results using common space scores as a proxy for ideology were similar. Two other sets of results also warrant note. First, judges with prior judicial experience as well as the more senior federal judges were less likely to reach proreligion decisions in school cases but not in nonschool cases. Second, we note that for school cases an increase in the percentage of the population that is Jewish in a jurisdiction increased the likelihood of a proreligion decision. In contrast, for nonschool cases an increase in

28 See Diane Ravitch, The Troubled Crusade: American Education, 1945-1980 29-32 (Basic Books 1983); Diane Ravitch, The Great School Wars: A History of the New York City Public Schools 168, 257, 362 (Johns Hopkins 2000).

29 See Tracey E. George, Court Fixing, 43 Ariz L Rev 9, 46 (2001) ("Where law and precedent provide weak guidelines rather than mandates, the judge's decision is more likely to be the product of attitudes and environment.").

30 See Gregory C. Sisk and Michael Heise, Ideology "All The Way Down"? An Empirical Study of Establishment Clause Decisions in the Federal Courts, 110 Mich L Rev *3, 6-30 (forthcoming 2012), online at http://papers.ssrn.com/sol3/papers.cfm?abstract_id=1791214 (visited Oct 27, 2011); Gregory C. Sisk and Michael Heise, Judges and Ideology: Public and Academic Debates about Statistical Measures, 99 Nw U L Rev 743, 764-69 (2005); Gregory C. Sisk, How Traditional and Minority Religions Fare in the Courts: Empirical Evidence from Religious Liberty Cases, 76 U Colo L Rev 1021, 1036-37 (2005); Sisk, Heise, and Morriss, 65 Ohio St L J at 555-57, 571-73 (cited in note 26).

31 See Part I. 
the percentage of Catholics decreased the likelihood of a proreligion outcome. ${ }^{32}$

This Article proceeds in two parts. Part I describes our data and research methods. Our principal results are discussed in Part II. In our Conclusion, we emphasize the limitations of our results and consider ways in which this line of research might be fruitfully expanded and developed in the future.

\section{DATA AND METHODOLOGY}

\section{A. Data}

Consistent with our prior empirical work on the federal courts, we focus on lower federal court judges and their decisions in cases raising constitutional religious freedom issues. ${ }^{33}$ Specifically, we created a database of the universe of digested decisions by the federal district courts and courts of appeals resolving challenges to the Establishment and Free Exercise Clauses from 1996 to $2005 .^{34}$ As the decisions were collected, the direction of each judge's ruling, the general factual category of the case, the religious affiliation of the judge, the religious demographics of the judge's community, the judge's ideology, the judge's race and gender, and various background and employment variables for the judge were coded..$^{35}$

We treated each individual judge's ruling in an individual case as a "judicial participation," which served as our unit of analysis. ${ }^{36}$ Each district judge's ruling was coded separately, as was each individual vote by the multiple judges participating on an appellate panel. Accordingly, the primary focus of our study was the judge rather than the court as an institution or a collective appellate panel. That is, we measured the individual response of each judge to each religion clauses claim.

\footnotetext{
32 See Part II.B.

33 See Gregory C. Sisk, Michael Heise, and Andrew P. Morriss, Charting the Influences on the Judicial Mind: An Empirical Study of Judicial Reasoning, 73 NYU L Rev 1377, 1415-16 (1998); Andrew P. Morriss, Michael Heise, and Gregory C. Sisk, Signaling and Precedent in Federal District Court Opinions, 13 S Ct Econ Rev 63, 67-72 (2005); Sisk and Heise, 99 Nw U L Rev at 761-62 (cited in note 30). For a discussion of why we feel a study of lower federal court opinions is especially apt in this context, see Sisk and Heise, 110 Mich L Rev at *7-9 (cited in note 30) (describing the rationale behind collecting data on federal circuit and district court opinions when evaluating the effects of judicial ideology on outcomes in religious freedom cases).

34 See note 46 and accompanying text.

35 For more detailed information about our study, data collection, and coding, see Sisk, Heise, and Morriss, 65 Ohio St L J at 529-53 (cited in note 26).

36 For a further discussion of judicial participations as the data point, see id at 539-41.
} 
A few research design points deserve attention. As our study endeavors to assess judicial decision making, we excluded decisions by Supreme Court justices from our data set. Although the Supreme Court has the final word in constitutional decisions, the lion's share of federal constitutional cases are resolved by lower federal courts. ${ }^{37}$ Also, owing to the small and stable number of justices serving on the Court, we find that empirical studies of the members of that unique institution sometimes migrate from social science to biography. Moreover, as discussed above, because the Supreme Court's jurisprudence regarding both the Establishment and Free Exercise Clauses has been unstable over time and uncertain in application, the district and appellate court judges have retained important decisional latitude in this area. While Supreme Court precedent certainly plays a key role in federal litigation in the lower courts, there remains substantial play in the doctrine as applied to an individual case and set of facts. For this reason, the body of litigation in the federal district courts and courts of appeals is particularly amenable to a meaningful empirical analysis of influences upon judicial decision making. Finally, we believe that for decades social scientists' and legal academics' focus on the Supreme Court may have come at the expense of scholarly attention to the lower federal courts. ${ }^{3 \%}$

Given our decision to focus on lower federal courts, however, our inclusion of district judges along with courts of appeals judges in this study and our coding both types of judges in the same way on merits decisions warrant discussion. Our effort to expand empirical study beyond circuit judges and evaluate the larger pool of lower federal judges has merit, particularly in the constitutional rulings context. To be sure, many scholars are conducting important research on district court judges through quantitative study of dockets and developments and rulings at the multiple stages of the civil litigation process. ${ }^{39}$ Recognizing that "the nature of district court judges' work is

37 See Pauline T. Kim, Lower Court Discretion, 82 NYU L Rev 383, 391 (2007).

38 Encouragingly, the traditional focus on the Supreme Court has been broadened in the last decade, with the federal courts of appeals and district courts becoming the subject of increasing attention among political scientists and legal academics doing empirical work. For a brief summary, see Sisk, Heise, and Morriss, 65 Ohio St L J at $529 \mathrm{n} 156$ (cited in note 26).

39 See, for example, Christina L. Boyd and David A. Hoffman, Disputing Limited Liability, 104 Nw U L Rev 853, 877-78 (2010); Pauline T. Kim, et al, How Should We Study District Judge Decision-Making?, 29 Wash U J L \& Pol 83, 101 (2009); James D. Cox, Randall S. Thomas, and Lynn Bai, There Are Plaintiffs and ... There Are Plaintiffs: An Empirical Analysis of Securities Class Action Settlements, 61 Vand L Rev 355, 367 (2008); David L. Schwartz, Practice Makes Perfect? An Empirical Study of Claim Construction Reversal Rates in Patent Cases, 107 Mich L Rev 223, 237 (2008). 
substantially different from that of appellate judges," many of these scholars tailor their empirical research to the distinct institutional setting of the district court. ${ }^{40}$ While we feel such work is important, we nonetheless concluded that a docket-oriented approach was neither possible nor particularly well-suited for our study of outcomes in religious cases. In the particular context of constitutional rulings, the appellate court's typical deferential posture regarding trial court factual determinations gives way to the "constitutional fact" exception for "factual" disputes that frequently reside at the heart of a constitutional question." Moreover, trial and appellate judges share parallel responsibilities for resolving contested constitutional questions, including the central constitutional significance of factual assertions, precisely "to prevent the idiosyncrasies of a single judge or jury from having far-reaching legal effects." ${ }^{42}$

As such, we first needed to place trial court rulings in the same decisional space as appellate court rulings, thus requiring us to focus on merits rulings and not preliminary nonmerits rulings. Second, we examined decisions from 1996 to 2005 , but the various federal docket and pleading databases are generally reliable only from $2000 .^{43}$ In particular, the restricted search options and limited nature of case coding of federal court dockets databases, especially when searching for cases raising religious-liberty issues, functionally precluded effective use of these sources for the time period of our study. ${ }^{44}$

A further complicating wrinkle flows from the small percentage of district court dispositions that generate a written opinion, ${ }^{45}$ which is

40 See Kim, et al, 29 Wash U J L \& Pol at 85, 101-06 (cited in note 39).

41 See Rankin v McPherson, 483 US 378, 385 n 8 (1987) (noting that trial court fact findings are subject to "constitutional fact review" by the appellate court). See also Henry $P$. Monaghan, Constitutional Fact Review, 85 Colum L Rev 229, 229-32 (1985).

42 See $A$ Woman's Choice-East Side Women's Clinic v Newman, 305 F3d 684, 689 (7th Cir 2002) ("That admixture of fact and law, sometimes called an issue of 'constitutional fact,' is reviewed without deference in order to prevent the idiosyncrasies of a single judge or jury from having far-reaching legal effects.").

43 See Boyd and Hoffman, 104 Nw U L Rev at 877 n 119, 880 (cited in note 39).

44 See Mary Whisner, Unanswerable Questions, 100 L Library J 581, 583 (2008) (noting that the "Nature of Suit" coding in the federal docket PACER system lacks the detail needed for finding many types of cases); Gillian K. Hadfield, Judging Science: An Essay on the Unscientific Basis of Beliefs about the Impact of Legal Rules on Science and the Need for Better Data about Law, $14 \mathrm{~J} \mathrm{~L} \&$ Pol 137, 144-45 (2006) (observing that cases are coded in the PACER docket for a single type, even if the cases involve multiple causes of action).

45 See David A. Hoffman, Alan J. Izenman, and Jeffrey R. Lidicker, Docketology, District Courts, and Doctrine, 85 Wash U L Rev 681, 710 \& n 139 (2007) (finding that only 18 percent of district court cases produced written decisions); Margo Schlanger and Denise Lieberman, Using Court Records for Research, Teaching, and Policymaking: The Civil Rights Litigation Clearinghouse, 75 UMKC L Rev 155, 165 (2006) (finding that 8.7 percent of terminated cases in federal district court left written decisions and 2.3 percent resulted in 
the data point for our study. For the high-visibility area of religion clauses challenges, however, we believe that the rate of district court dispositions through written, even published, decisions is much higher than the base rate. To test our belief, a spot check of a hundred Establishment Clause complaints produced in a search of the Westlaw pleadings database revealed that nearly three-quarters lead to written decisions, most of which were also published. To be sure, our search process undoubtedly captured a larger share of appellate rather than district court activity. In our school case subset we find 78 district court judicial participations (24.1 percent) and 246 appellate court judicial participations (75.9 percent). Accordingly, readers fairly might place greater weight on our findings with respect to court of appeals judges than to district court judges.

In our prior study of 1986-1995 religious-liberty decisions, for substantive and practical reasons, we included only published decisions in our database. In so doing, we knowingly "biased our database in favor of decisions that raise highly visible, controversial, landmark, or difficult questions of religious freedom, or at least issues of religious freedom that a judicial actor found particularly interesting and thus worthy of publication." ${ }^{\prime 46}$ For this 1996-2005 study, we have expanded the database to include the set of unpublished but digested opinions available on Westlaw. In addition to 1,921 judicial participations from published decisions, our data set includes 401 judge votes from decisions that were digested by Westlaw but not published in the reporter system. Because not all decisions, even those that are written, are digested, the data set still is likely to be skewed to the more significant decisions. Thus, our data set may be biased toward decisions that raise highly visible, controversial, landmark, or difficult questions of religious freedom, or at least issues of religious liberty that a judicial actor found particularly interesting. Fortunately, those are precisely the types of decisions that we would wish to analyze for evidence of variation among judges in their response to significant constitutional problems upon which reasonable people could disagree.

reported decisions); Susan M. Olson, Studying Federal District Courts through Published Cases: A Research Note, 15 Just Sys J 782, 789-90 (1992) (finding that 5.3 percent of the district court cases in the study resulted in published decisions, with significant variation in the publication rate among different types of cases).

46 Sisk, $76 \mathrm{U}$ Colo L Rev at 1049 (cited in note 30). 
Having decided to focus on published and digested decisions, we conducted a search on Westlaw for all decisions ${ }^{47}$ in which the digests of the opinions prepared by West include the terms "free exercise," "establishment clause," "establishment of religion," "religious freedom restoration act," or "equal access act." In addition, we searched for the appearance in the opinion digests of "free speech," "equal protection," "due process," "title vii," and "discrimination" as connected to religious phrases. ${ }^{48}$

To be coded as a decision on the merits, a ruling by a district judge must have accepted or rejected a particular claim in a manner that engaged the underlying merits of the claim, even if the ruling was not a final judgment. We excluded nonmerits justiciability decisions and procedural rulings from our study. ${ }^{49}$ For court of appeals judges, a ruling was coded on the merits if it affirmed or reversed a final judgment by a district court on an Establishment or Free Exercise Clause claim or remanded the case after an evaluation of a significant element of the merits of the claim." If a three-judge appellate panel issued a decision that later was reheard en banc (or was the subject of a dissent from the denial of rehearing en banc), each judge was recorded as having cast only one judicial vote, even if the judge participated on both the three-judge panel and the en banc panel (or the dissent from the denial of rehearing). ${ }^{51}$

Our dependent variable, proreligion, reflects the direction of the individual judge's vote in each case, coded as " 1 " when the outcome favored religion and as " 0 " when religion was disfavored. We crafted our dependent variable by blending two distinct streams of cases. Thus, decisions upholding free exercise or related accommodation claims (thus affirming the vitality of the religious exercise or expression and elevating it above nonvital governmental controls) and decisions rejecting Establishment Clause claims (thus approving

47 By adopting the universe of decisions in the selected time period as the basis for collecting the data, we avoid issues of sampling in this study, other than, of course, the problem of our unavoidable omission of unpublished decisions, discussed earlier. See Part I.B.

48 As evidenced in our description of the background variables for the judges involved in this study, the US Appeals Courts Database, for which Professor Donald R. Songer at the University of South Carolina was the principal investigator, is an invaluable resource. See Donald R. Songer, US Appeals Courts Database (The Judicial Research Initiative at the University of South Carolina), online at http://www.cas.sc.edu/poli/juri/appct.htm (visited Oct $28,2011)$. However, as will be apparent in what follows, the scope of religious-liberty decisions that we wish to explore is more expansive than is captured in that database's coding of court of appeals decisions in such categories as free exercise of religion and establishment of religion.

49 See Sisk, Heise, and Morriss, 65 Ohio St L J at 546 (cited in note 26).

so See id at $547-48$.

51 See id at 552-53. 
governmental acknowledgment or support, at least on a neutral basis, for religious sentiments or institutions) were treated as decisions favoring religion. In contrast, decisions that rejected free exercise or related accommodation claims as well as decisions upholding Establishment Clause claims were treated as disfavoring religion.

Of course, by adopting a "favoring" and "disfavoring" religion coding scheme, we in no way intend to imply that any individual judge or scholar who resists giving preferential treatment to religious practice under the Free Exercise Clause or who insists upon a strict separation of church and state under the Establishment Clause is hostile to religious faith or is in any way antireligious. Rather, we adopt a more positive tack by suggesting that a person who takes the position of upholding the priority of religious practice in the absence of a compelling governmental interest and who generally approves of the open participation of religious individuals in community affairs and the accommodation of religious institutions with government can be plausibly characterized as proreligion in public life.

Our final data set consists of 2,322 judicial participations, drawn from 1,091 distinct decisions. As Table 1 illustrates, of the universe of judicial participations, 324 involved elementary or secondary schools (public and nonpublic). In our subset of school cases, just under one-half (46.9 percent) were classified as proreligion outcomes. While the overwhelming majority (81.1 percent) of other cases (that is, cases not involving schools) dealt with Free Exercise Clause claims, within the smaller subset of school cases, Free Exercise claims were a slight minority (45.4 percent). In summary, the particular subset of judicial participations of interest, school cases, benefits from a relatively equal mix of proreligion and nonproreligion outcomes as well as Free Exercise and Establishment Clause claims.

TABLE 1. SUMMARY OF CASE TYPES (1996-2005)

\begin{tabular}{|c|c|c|c|c|}
\hline & Establishment & $\begin{array}{r}\text { Free } \\
\text { Exercise }\end{array}$ & & Proreligion \\
\hline & Clause & Clause & $(N)$ & Decision \\
\hline All Cases: & 555 & 1,767 & 2,322 & 955 \\
\hline School Cases: & 177 & 147 & 324 & 152 \\
\hline
\end{tabular}


B. Methodology

Our effort to model the likelihood of proreligion decisions draws heavily on our prior work. ${ }^{52}$ Because we analyzed the influences of an array of independent variables, multiple regression models were adopted. As our dependent variable is dichotomous, we estimated logistic regression models."3 Our two primary models (using different proxies for ideology) were nearly identical in the percentage of the overall variation explained and were largely parallel in statistically significant variable correlations.

Our independent variables are organized into three broad categories: case types, judges' background and demography, and community demography. As for case types, insofar as we are particularly interested in the proreligion decisions in the education context, "School Case" identifies those cases involving private or public elementary or secondary schools. Moreover, for reasons we describe more fully below, we felt that legal theory as well as the practical distribution of our data support including a dummy variable, "Establishment Clause Case," which permits us to distinguish between the two distinct streams of decisions in our data set (Establishment and Free Exercise Clause decisions). This distinction is necessary as a control, as we believe that the Establishment and Free Exercise Clause cases were likely to systematically differ in terms of their probability of generating a proreligion outcome. Indeed, at the descriptive level, results in Table 2 suggest as much. Of the 147 Establishment Clause cases involving schools, 101 (or 68.7 percent) resulted in proreligion decisions. In contrast, of the 177 free exercise cases, only 71 (or 40.1 percent) generated proreligion decisions.

52 See Sisk, Heise, and Morriss, 65 Ohio St L J at 557, 572, 614 (cited in note 26); Sisk and Heise, $99 \mathrm{Nw}$ U L Rev at 764-67 (cited in note 30); Sisk, $76 \mathrm{U}$ Colo L Rev at 1036-37 (cited in note 30 ) (revealing that the claimant's religion influences the likelihood that he or she will prevail in a religious freedom case); Sisk and Heise, 110 Mich L Rev at *3 (cited in note 30).

53 See Sisk, Heise, and Morriss, 65 Ohio St L J at 553-54 \& n 235 (cited in note 26). 


\section{TABle 2. Distribution of PRORELIGION DeCISIONS IN SCHOOL CASES, BY CASE TYPE}

\begin{tabular}{lrr} 
& Proreligion & Non-proreligion \\
\hline Case Type: & & \\
$\quad$ Establishment & 46 & 101 \\
$\quad$ Clause & & \\
Free Exercise & 106 & 71 \\
$\quad$ Clause & & \\
$(N)$ & 152 & 172
\end{tabular}

Although our interest dwells on whether judicial decisions are proreligion, our research necessarily draws on the larger judicial decision-making literature. ${ }^{54}$ As such, a second category of independent variables focuses on the judges-specifically, their religion, background, gender, and ideology. For background information on judges we drew on several sources, including standard biographies on federal judges, ${ }^{55}$ online databases, ${ }^{56}$ independent research into the records of Senate judicial confirmation hearings at the National Archives, and an earlier survey of federal judges on certain subjects where the information was uncertain. ${ }^{57}$

To the extent that the religious demographics of the community in which the judge maintains chambers (the Catholic percentage in the community, the Jewish percentage in the community, and the total adherence rate to any religious group in a community) might inform judicial outcomes, we include those variables. Finally, to

54 See, for example, Thomas J. Miles and Cass R. Sunstein, The New Legal Realism, 75 U Chi L Rev 831, 832-33 (2008).

55 See 1 Almanac of the Federal Judiciary 1-2 (Aspen 2011); 2 Almanac of the Federal Judiciary 1-2 (Aspen 2011); Marie T. Finn, et al, eds, The American Bench: Judges of the Nation v-vi (Forster-Long 21st ed 2011); Biographical Directory of the Federal Judiciary 1789-2000 ix-x (Bernan 2001); Who's Who in American Law vi (Marquis Who's Who 17th ed 2011).

56 In particular, we obtained valuable information from Gary Zuk, Deborah J. Barrow, and Gerard S. Gryski, Multi-user Database on the Attributes of United States Appeals Court Judges, 1801-2000 (National Archive of Criminal Justice Data 2010), online at http://dx.doi.org/10.3886/icpsr06796 (visited Oct 28, 2011).

57 When we conducted a survey of certain judges on whom data was uncertain about prior employment background, we obtained an extraordinary rate of return from the federal judges to whom the survey was sent, in excess of 90 percent. The National Archives research on Senate judicial confirmation hearings and the survey responses from the federal judges who were contacted are on file with the authors. 
account for any possible time trend during the ten years of data, we also include the year of decision as a variable.

\section{RESULTS AND DISCUSSION}

We estimate a proreligion judicial outcome model for lower federal court cases that involved elementary and secondary schools using logistic regression. Table 3 presents our results.

TABLE 3. LOGISTIC REgRESSION ANALYSIS FOR PRORELIGION MODEL, FEDERAL COURTS (1996-2005)
(1)
(2)
(3)
(4)
(5)
(6)

All School Other All School Other

\begin{tabular}{lrrr|rrr} 
& Cases & \multicolumn{1}{c}{ Cases } & \multicolumn{1}{c}{ Cases } & \multicolumn{1}{c}{ Cases } & \multicolumn{1}{c}{ Cases } & Cases \\
\hline School Case & -0.079 & --- & --- & -0.073 & --- & --- \\
& $(.165)$ & & & $(.165)$ & & \\
Establishment & $0.982^{* *}$ & $0.957^{* *}$ & $0.968^{* *}$ & $0.986^{* *}$ & $0.991^{* *}$ & $0.969^{* *}$ \\
Clause Case & $(.148)$ & $(.321)$ & $(.131)$ & $(.147)$ & $(.310)$ & $(.130)$ \\
Judge Religion: & & & & & & \\
Catholic & -0.017 & 0.130 & -0.014 & -0.022 & 0.173 & -0.021 \\
& $(.129)$ & $(.417)$ & $(.130)$ & $(.130)$ & $(.425)$ & $(.133)$ \\
Baptist & -0.232 & -0.118 & -0.204 & -0.231 & -0.096 & -0.200 \\
& $(.174)$ & $(.789)$ & $(.148)$ & $(.170)$ & $(.825)$ & $(.142)$ \\
Other & -0.206 & -0.309 & -0.189 & -0.215 & -0.452 & -0.193 \\
Christian & $(.128)$ & $(.565)$ & $(.133)$ & $(.124)$ & $(.524)$ & $(.132)$ \\
Jewish & -0.032 & -0.657 & 0.068 & -0.044 & -0.608 & 0.056 \\
& $(.217)$ & $(.492)$ & $(.220)$ & $(.217)$ & $(.478)$ & $(.222)$ \\
Other & -0.154 & -0.605 & -0.107 & -0.168 & -0.714 & -0.121 \\
& $(.189)$ & $(.853)$ & $(.184)$ & $(.199)$ & $(.754)$ & $(.193)$ \\
None & -0.095 & -0.091 & -0.109 & -0.097 & -0.062 & -0.116 \\
& $(.149)$ & $(.619)$ & $(.182)$ & $(.156)$ & $(.597)$ & $(.188)$ \\
Judge Sex & & & & & & \\
and Race: & & & & & & \\
Sex (Female) & 0.133 & 0.489 & 0.084 & 0.140 & 0.580 & 0.083 \\
& $(.099)$ & $(.471)$ & $(.095)$ & $(.104)$ & $(.461)$ & $(.103)$ \\
African & 0.151 & -0.370 & 0.242 & 0.153 & -0.249 & 0.235 \\
American & $(.165)$ & $(.467)$ & $(.189)$ & $(.179)$ & $(.474)$ & $(.198)$ \\
Asian/Latino & $0.460^{*}$ & -0.213 & $0.533^{* *}$ & $0.488^{*}$ & -0.011 & $0.542^{* *}$ \\
& $(.216)$ & $(.987)$ & $(.183)$ & $(.210)$ & $(.896)$ & $(.182)$ \\
\hline
\end{tabular}




\begin{tabular}{|c|c|c|c|c|c|c|}
\hline & $\begin{array}{c}(1) \\
\text { All } \\
\text { Cases } \\
\end{array}$ & $\begin{array}{c}(2) \\
\text { School } \\
\text { Cases }\end{array}$ & $\begin{array}{c}(3) \\
\text { Other } \\
\text { Cases }\end{array}$ & $\begin{array}{c}(4) \\
\text { All } \\
\text { Cases } \\
\end{array}$ & $\begin{array}{c}(5) \\
\text { School } \\
\text { Cases }\end{array}$ & $\begin{array}{c}\text { (6) } \\
\text { Other } \\
\text { Cases }\end{array}$ \\
\hline \multicolumn{7}{|l|}{$\begin{array}{l}\text { Judge Ideology } \\
\text { or Attitude: }\end{array}$} \\
\hline $\begin{array}{l}\text { Common } \\
\text { Space Score }\end{array}$ & $\begin{array}{r}0.295 \\
(.155)\end{array}$ & $\begin{array}{r}1.539 * * \\
(.423)\end{array}$ & $\begin{array}{r}0.158 \\
(.151)\end{array}$ & --- & --- & -.. \\
\hline $\begin{array}{l}\text { Party of } \\
\text { Appointing } \\
\text { President }\end{array}$ & --- & --- & --- & $\begin{array}{r}0.202 \\
(.140)\end{array}$ & $\begin{array}{r}1.189^{* *} \\
(.423)\end{array}$ & $\begin{array}{r}0.089 \\
(.128)\end{array}$ \\
\hline $\begin{array}{l}\text { ABA } \\
\text { Rating- } \\
\text { Above } \\
\text { Qualified }\end{array}$ & $\begin{array}{r}0.002 \\
(.097)\end{array}$ & $\begin{array}{l}-0.011 \\
(.324)\end{array}$ & $\begin{array}{c}-0.015 \\
(.099)\end{array}$ & $\begin{array}{r}0.012 \\
(.098)\end{array}$ & $\begin{array}{r}0.053 \\
(.315)\end{array}$ & $\begin{array}{l}-0.010 \\
(.099)\end{array}$ \\
\hline $\begin{array}{l}\text { ABA } \\
\text { Rating- } \\
\text { Below } \\
\text { Qualified }\end{array}$ & $\begin{array}{r}0.186 \\
(.150)\end{array}$ & $\begin{array}{l}0.731 \\
(.646)\end{array}$ & $\begin{array}{r}0.104 \\
(.142)\end{array}$ & $\begin{array}{r}0.201 \\
(.138)\end{array}$ & $\begin{array}{l}0.868 \\
(.582)\end{array}$ & $\begin{array}{r}0.117 \\
(.134)\end{array}$ \\
\hline $\begin{array}{l}\text { Seniority on } \\
\text { Federal } \\
\text { Bench }\end{array}$ & $\begin{array}{l}-0.000 \\
(.000)\end{array}$ & $\begin{array}{r}-0.002^{*} \\
(.001)\end{array}$ & $\begin{array}{r}0.000 \\
(.000)\end{array}$ & $\begin{array}{l}-0.000 \\
(.000)\end{array}$ & $\begin{array}{r}-0.003^{*} \\
(.001)\end{array}$ & $\begin{array}{r}0.000 \\
(.000)\end{array}$ \\
\hline $\begin{array}{l}\text { Elite Law } \\
\text { School }\end{array}$ & $\begin{array}{l}-0.026 \\
(.047)\end{array}$ & $\begin{array}{r}0.058 \\
(.314)\end{array}$ & $\begin{array}{c}-0.038 \\
(.048)\end{array}$ & $\begin{array}{l}-0.029 \\
(.050)\end{array}$ & $\begin{array}{r}0.034 \\
(.335)\end{array}$ & $\begin{array}{l}-0.042 \\
(.049)\end{array}$ \\
\hline \multicolumn{7}{|l|}{$\begin{array}{l}\text { Judge } \\
\text { Employment } \\
\text { Background: }\end{array}$} \\
\hline Military & $\begin{array}{r}0.037 \\
(.089)\end{array}$ & $\begin{array}{l}0.651 \\
(.419)\end{array}$ & $\begin{array}{r}-0.049 \\
(.083)\end{array}$ & $\begin{array}{r}0.033 \\
(.089)\end{array}$ & $\begin{array}{r}0.676 \\
(.407)\end{array}$ & $\begin{array}{l}-0.051 \\
(.084)\end{array}$ \\
\hline Government & $\begin{array}{r}-0.020 \\
(.069)\end{array}$ & $\begin{array}{l}-0.447 \\
(.252)\end{array}$ & $\begin{array}{r}0.017 \\
(.059)\end{array}$ & $\begin{array}{l}-0.021 \\
(.069)\end{array}$ & $\begin{array}{l}-0.463 \\
(.246)\end{array}$ & $\begin{array}{r}0.017 \\
(.059)\end{array}$ \\
\hline $\begin{array}{l}\text { State or Local } \\
\text { Judge }\end{array}$ & $\begin{array}{l}-0.152 \\
(.098)\end{array}$ & $\begin{array}{r}-0.670^{*} \\
(.274)\end{array}$ & $\begin{array}{l}-0.047 \\
(.089)\end{array}$ & $\begin{array}{l}-0.167 \\
(.099)\end{array}$ & $\begin{array}{r}-0.753^{*} \\
(.261)\end{array}$ & $\begin{array}{r}-0.055 \\
(.091)\end{array}$ \\
\hline $\begin{array}{l}\text { Law } \\
\text { Professor }\end{array}$ & $\begin{array}{r}0.188 \\
(.137)\end{array}$ & $\begin{array}{r}0.345 \\
(.510)\end{array}$ & $\begin{array}{r}0.242 \\
(.126)\end{array}$ & $\begin{array}{r}0.174 \\
(.134)\end{array}$ & $\begin{array}{r}0.193 \\
(.529)\end{array}$ & $\begin{array}{r}0.235 \\
(.125)\end{array}$ \\
\hline \multicolumn{7}{|l|}{$\begin{array}{l}\text { Community } \\
\text { Demographics: }\end{array}$} \\
\hline $\begin{array}{l}\text { Catholic } \\
\text { Percentage }\end{array}$ & $\begin{array}{r}-0.013^{* *} \\
(.004)\end{array}$ & $\begin{array}{l}-0.008 \\
(.016)\end{array}$ & $\begin{array}{r}-0.012 * * \\
(.004)\end{array}$ & $\begin{array}{r}-0.014 * * \\
(.004)\end{array}$ & $\begin{array}{l}-0.014 \\
(.015)\end{array}$ & $\begin{array}{r}-0.013^{* *} \\
(.004)\end{array}$ \\
\hline $\begin{array}{l}\text { Jewish } \\
\text { Percentage }\end{array}$ & $\begin{array}{r}0.004 \\
(.009)\end{array}$ & $\begin{array}{r}0.054^{*} \\
(.027)\end{array}$ & $\begin{array}{l}-0.003 \\
(.008)\end{array}$ & $\begin{array}{r}0.003 \\
(.009)\end{array}$ & $\begin{array}{r}0.050^{*} \\
(.023)\end{array}$ & $\begin{array}{r}-0.003 \\
(.008)\end{array}$ \\
\hline $\begin{array}{l}\text { Adherence } \\
\text { Rate }\end{array}$ & $\begin{array}{r}0.008 \\
(.005)\end{array}$ & $\begin{array}{l}-0.016 \\
(.023)\end{array}$ & $\begin{array}{r}0.009 \\
(.004)\end{array}$ & $\begin{array}{r}0.008 \\
(.005)\end{array}$ & $\begin{array}{l}-0.013 \\
(.022)\end{array}$ & $\begin{array}{r}0.009^{*} \\
(.004)\end{array}$ \\
\hline
\end{tabular}




\begin{tabular}{|c|c|c|c|c|c|c|}
\hline & $\begin{array}{c}(1) \\
\text { All } \\
\text { Cases }\end{array}$ & $\begin{array}{c}(2) \\
\text { School } \\
\text { Cases }\end{array}$ & $\begin{array}{c}(3) \\
\text { Other } \\
\text { Cases }\end{array}$ & $\begin{array}{c}(4) \\
\text { All } \\
\text { Cases } \\
\end{array}$ & $\begin{array}{c}(5) \\
\text { School } \\
\text { Cases }\end{array}$ & $\begin{array}{c}(6) \\
\text { Other } \\
\text { Cases } \\
\end{array}$ \\
\hline $\begin{array}{l}\text { Year of } \\
\text { Decision }\end{array}$ & $\begin{array}{r}0.013 \\
(.015)\end{array}$ & $\begin{array}{r}0.035 \\
(.085)\end{array}$ & $\begin{array}{r}0.009 \\
(.015)\end{array}$ & $\begin{array}{r}0.014 \\
(.015)\end{array}$ & $\begin{array}{r}0.046 \\
(.085)\end{array}$ & $\begin{array}{r}0.010 \\
(.016)\end{array}$ \\
\hline (Constant) & -27.250 & -68.472 & -19.009 & -29.139 & -91.836 & -20.077 \\
\hline Pseudo R2 & 0.043 & 0.169 & 0.034 & 0.042 & 0.172 & 0.034 \\
\hline $\begin{array}{l}\text { Percent } \\
\text { Correctly } \\
\text { Classified }\end{array}$ & 64.13 & 70.37 & 63.46 & 63.95 & 69.14 & 63.36 \\
\hline$(N)$ & 2322 & 324 & 1998 & 2322 & 324 & 1998 \\
\hline
\end{tabular}

Notes: Proreligion Outcome $=1 .{ }^{*} \mathrm{p}<.05 ;{ }^{* *} \mathrm{p}<.01$. Standard error adjusted for 13 clusters in circuits.

A. Findings on Political Party and Ideology Variables

In this study, "the 'Pro-Religion' dependent variable measures a particular robust view about the propriety of religion in public life, ${ }^{\prime 38}$ or, in this focused study on education, about the visibility and presence of religion and religious viewpoints in public school and public support for parents who wish their children to attend private religious schools. Opponents of public recognition or accommodation of religion in this educational context should not casually be characterized as "harbor[ing] antipathy toward faith or religious believers outside of this peculiar legal context," $"$ "sy but rather as adopting a strict separationist or secularist perspective toward interactions with religion in this particular realm of public life.

As Table 3 illustrates, in federal court cases that arise at the intersection between the religion clauses of the First Amendment and elementary and secondary education, political ideology emerges as a robust predictor of outcomes. Holding all other variables constant, a Republican-appointed judge was nearly twice as likely to vote in a proreligion direction (at a rate of 59 percent) as was a Democratic-appointed judge (at a rate of 30 percent). Using common space scores as a proxy for ideology, the more conservative judges were predicted to choose the proreligion side of the case at a 63.7 percent rate, compared with a predicted probability of a vote in that direction of only 26.6 percent by the more liberal judges.

In two other phases of our religious-liberty decisions study, we have separately explored the influences on federal judges when deciding Establishment Clause and Free Exercise Clause cases

58 Sisk, Heise, and Morriss, 65 Ohio St $\mathrm{L} \mathrm{J}$ at 508 (cited in note 26).

59 Id. 
generally (including both education and noneducation cases). In our overall examination of Establishment Clause decisions in the federal courts from 1996 to 2005, we found a powerful ideological or political party influence on outcomes. Holding other variables constant, Democratic-appointed judges were predicted to uphold Establishment Clause challenges at a 57.3 percent rate, while the predicted probability of success fell to 25.4 percent before Republican-appointed judges. ${ }^{\circ 0}$ By contrast, in the "Religious Free Exercise/Accommodation" phase of the study, the lead story was the impaired success rate for Muslim claimants, not the political leanings of judges. ${ }^{61}$

Knowing that political variables were significant and potent in the general Establishment Clause case context, while not significant in the general Free Exercise Clause case context, we included a dummy variable for Establishment Clause cases in this combined educationfocused study so that the demonstrated political salience of Establishment Clause cases would not drive the results. Importantly, even with that control, ideology measured in alternative ways emerged as a highly significant and substantively strong influence on the outcome in school cases. In sum, what we observe here is not merely a side effect of the political influences on Establishment Clause decisions (as contrasted with Free Exercise decisions). Instead, we believe we have likely uncovered something specific to the education setting when Establishment Clause and Free Exercise decisions are examined together in the public and private elementary and secondary school context.

\section{Party of appointing President.}

Although crude and subject to multiple qualifications, the simplest, most commonly used, most unambiguously reliable (for accurate coding), most frequently verified as a meaningful and stable influence on judges, and most easily interpreted measure as a proxy for judicial ideology is party of appointing President (Republican or Democrat).$^{62}$ For each judge casting a vote in a religious-liberty case in our study, appointment by a Republican President was coded as

60 See Sisk and Heise, 110 Mich L Rev at *14-15 (cited in note 30).

61 Gregory C. Sisk and Michael Heise, Muslims and Religious Liberty in the Era of 9/11: Empirical Evidence from the Federal Courts *4-5 (unpublished manuscript, Aug 2011), online at http://papers.ssrn.com/sol3/papers.cfm?abstract_id=1917057 (visited Oct 21, 2011).

62 See Joshua B. Fischman and David S. Law, What Is Judicial Ideology, and How Should We Measure It? 29 Wash U J L \& Pol 133, 167-68 (2009). For further discussion of this proxy for ideology and its suitability in the religious-liberty study context, see Sisk and Heise, 110 Mich L Rev at "13 (cited in note 30). 
"1" and by a Democratic President as " 0 ." Of the 2,322 judicial participations on religious-liberty cases overall, 1,263 (or 54.4 percent) were by judges appointed by a Republican President and 1,059 (or 45.6 percent) were by judges appointed by a Democratic President.

Insofar as our alternative measures of ideology achieve significance, both warrant closer examination. As shown in Figure 1, holding all other independent variables constant at their means, the predicted probability that a Republican-appointed judge would vote in a proreligion direction is 59 percent, while the probability for a Democratic-appointed judge was 30.1 percent - a margin difference of 28.9 percent. $^{63}$ Thus, for the party that sought a religious accommodation or defended a public interaction with religion, the chance of success nearly doubled before a Republican-appointed judge, as compared to a Democratic-appointed judge.

63 The vertical lines in Figure 1 represent the 95 percent confidence intervals for these two predictions. Thus, while our best estimate is that a Republican-appointed judge is 59 percent likely to rule in a proreligion direction, the probability could be as low as 49.2 percent or as high as 67.9 percent. Similarly, while we predict that a Democratic-appointed judge would vote for the proreligion side of the case 30.1 percent of the time, the probability could be as low as 16.4 percent or as high as 43.8 percent. Because the probability that the comparative values would appear both in the higher end of the interval for a Republicanappointed judge and in the lower end of the interval for a Democratic-appointed judge is much lower than 5 percent, we are confident that the margin is higher, probably much higher, than the 5.4 percent margin between the low and high ends of these two confidence intervals. 
Figure 1. PREdicted Probability of a ProReligion Vote by JUDGE IN SCHOOL CASES, BY PARTY OF APPOINTING PRESIDENT

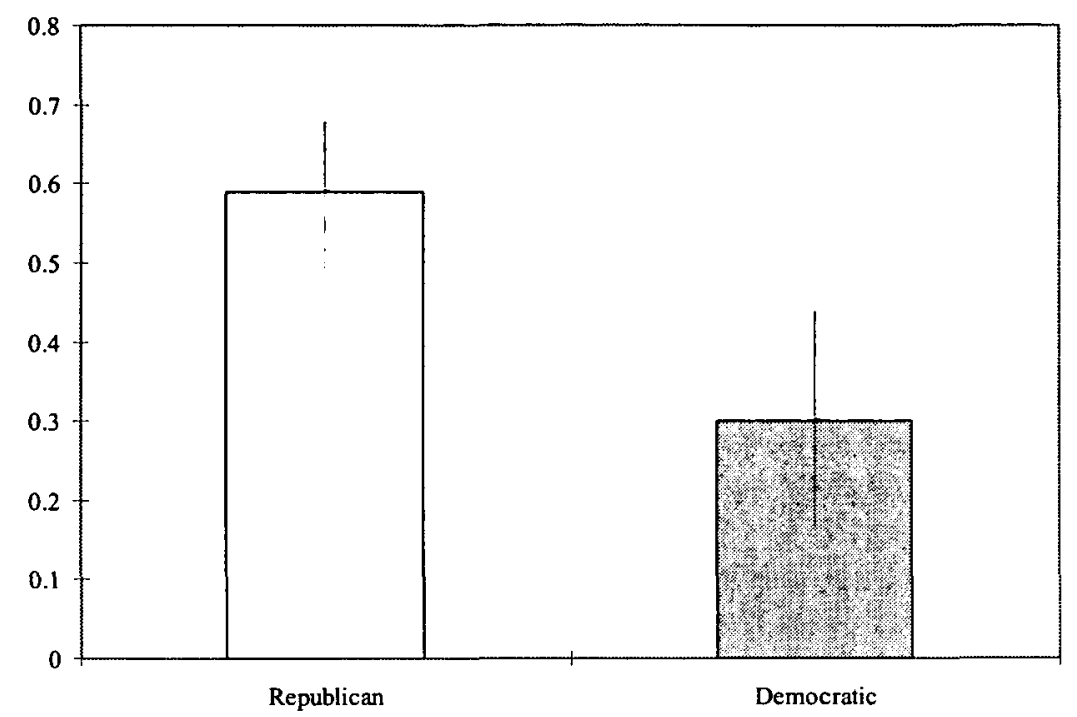

Note: Figure 1 draws from Table 3, column 5.

Our political culture influences the agendas and policy goals of those individuals who compete for the presidency, and in the United States the two major political parties help shape the political culture. As a result, the ways in which the two major political parties approach religion and education policy warrant brief discussion. During the past few decades, a "devotional divide" has opened in American politics and become embodied in the two major political parties and their platforms. "All else equal," Professor William Galston writes, "the more often individuals attend church, the more likely they are to regard themselves as conservatives and vote Republican." Bs Based on its 2008 survey of "religious intensity" and social and political views, the Pew Forum on Religion \& Public Life found that "[a]cross a variety of religious traditions, those who say that religion is very important in their lives, express a more certain belief in God, or pray or attend worship services more frequently tend to be much more conservative in their political outlook and

64 David E. Campbell, A House Divided? What Social Science Has to Say about the Culture War, 15 Wm \& Mary Bill Rts J 59, 64 (2006). For a general discussion of the religious divide in partisan identification, see Sisk and Heise, 110 Mich L Rev at *36-37 (cited in note 30).

65 William A. Galston, Political Polarization and the U.S. Judiciary, 77 UMKC L Rev 307, 318-19 (2008). 
more Republican in their party affiliation." ${ }^{\circ 6}$ While many persons of faith continue to affiliate with liberal political movements, the Democratic Party has become the political home for secularists, who have become a key constituency in the party and especially among party activists. ${ }^{67}$ By 1992, fewer than one-third of all delegates to the Democratic Convention attended church regularly, fewer than onequarter found religion to be highly salient in their lives, and more than 60 percent qualified as secularist in outlook. ${ }^{68}$

On the specific topic of education, the platforms of the political parties confirm that Republicans look favorably at efforts to acknowledge, accommodate, and interact with religion in the educational setting, while Democrats look more skeptically at the introduction of religion or religious influences into public education or the inclusion of private religious school options in public programs. Since 1972, every national Republican Party platform has called for the return of prayer to schools. ${ }^{.9}$ The most recent national

66 The Pew Forum on Religion \& Public Life, U.S. Religious Landscape Survey; Religious Beliefs and Practices: Diverse and Politically Relevant 19 (Pew Research Center 2008), online at http://religions.pewforum.org/pdf/report2-religious-landscape-study-full.pdf (visited Oct 21, 2011).

67 Andrew Kohut, et al, The Diminishing Divide: Religion's Changing Role in American Politics 3, 89 (Brookings 2000).

68 Geoffrey Layman, The Great Divide: Religious and Cultural Conflict in American Party Politics 105-09, 124 (Columbia 2001) (providing data on the religious beliefs and practices of delegates to the Democratic Conventions from 1972 to 1992).

69 See Republican National Committee, 2008 Republican Platform 44-45, 53-54 (The American Presidency Project 2011), online at http://www.presidency.ucsb.edu/papers_pdf /78545.pdf (visited Oct 22, 2011); Republican National Committee, 2004 Republican Party Platform: A Safer World and a More Hopeful America 82 (The American Presidency Project 2011), online at http:/www.presidency.ucsb.edu/papers_pdf/25850.pdf (visited Oct 22, 2011); Republican National Committee, Republican Party Platform of 2000 (The American Presidency Project 2011), online at http://www.presidency.ucsb.edu/ws/index.php?pid=25849 (visited Oct 22, 2011); Republican National Committee, Republican Party Platform of 1996 (The American Presidency Project 2011), online at http://www.presidency.ucsb.edu/ws /index.php?pid=25848 (visited Oct 22, 2011); Republican National Committee, Republican Party Platform of 1992: The Vision Shared; The Republican Platform, Uniting Our Family, Our Country, Our World (The American Presidency Project 2011), online at http:// www.presidency.ucsb.edu/ws/index.php ?pid=25847 (visited Oct 22, 2011); Republican National Committee, Republican Party Platform of 1988: An American Vision; For Our Children and Our Future (The American Presidency Project 2011), online at http://www.presidency.ucsb.edu/ws/index.php?pid=25846 (visited Oct 22, 2011); Republican National Committee, Republican Party Platform of 1984: American's Future Free and Secure (The American Presidency Project 2011), online at http:// www.presidency.ucsb.edu/ws/index.php?pid=25845 (visited Oct 22, 2011); Republican National Committee, Republican Party Platform of 1980 (The American Presidency Project 2011), online at http://www.presidency.ucsb.edu/ws/index.php?pid=25844 (visited Oct 22, 2011); Republican National Committee, Republican Party Platform of 1976 (The American Presidency Project 2011), online at http://www.presidency.ucsb.edu/ws/index.php?pid=25843 (visited Oct 22, 2011); Republican National Committee, Republican Party Platform of 1972 
Republican Party platform (2008) "energetically assert[s] the right of students to engage in voluntary prayer in schools and to have equal access to school facilities for religious purposes." ${ }^{\prime \prime 0}$ During this period, the word "prayer" has never appeared in national Democratic Party platforms."

State Republican Party platforms have been even more emphatic in approval of prayer and acceptance of a religious presence in publicly supported education. For example, the current platform of the Republican Party of Iowa says that "Judeo-Christian values and Scripture should not be excluded from the public schools," while Texas Republican platforms regularly "urge school administrators and officials to inform Texas school students specifically of their First Amendment rights to pray and engage in religious speech, individually or in groups, on school property without government interference."'s More capaciously, the Oklahoma Republican Party platform of 2009

affirm[ed] the right of students and teachers to the free exercise of religion as guaranteed by the First Amendment, including the right to wear and display religious symbols, voluntary vocal prayer, optional Bible and religious study, religious expression including holidays, and equal access to use of school facilities for these activities. ${ }^{74}$

By contrast, the Colorado and Minnesota Democratic Party platforms of 2010 specifically "support the separation of church and

(The American Presidency Project 2011), online at http://www.presidency.ucsb.edu/ws /index.php?pid=25842 (visited Oct 22, 2011).

70 Republican National Committee, 2008 Republican Platform at 44-45 (cited in note 69).

71 See, for example, Democratic National Committee, Democratic Party Platform of 1996: Today's Democratic Party; Meeting America's Challenges, Protecting America's Values (The American Presidency Project 2011), online at http://www.presidency.ucsb.edu/ws /index.php ?pid=29611 (visited Oct 22, 2011) (applauding "the President's work to ensure that children are not denied private religious expression in school" without specifically mentioning prayer).

72 Republican Party of Iowa, Our Platform $\$ \S 4.30$ to 4.32 (2011), online at http://iowagop.org/platform.php (visited Oct 22, 2011).

73 See, for example, Republican Party of Texas, 2010 State Republican Party Platform 14 (Texas Tribune 2010), online at http://static.texastribune.org/media/documents/FINAL_2010 _STATE_REPUBLICAN_PARTY_PLATFORM.pdf (visited Oct 22, 2011); Republican Party of Texas, 2004 State Republican Party Platform 17 (Internet Archive 2009), online at http://ia600303.us.archive.org/18/items/TexasRepublicanPartyPlatform/TexasRPTPlatform200 4.pdf (visited Oct 22, 2011).

74 Oklahoma Republican Party, Report of the Oklahoma Republican Party Platform Committee 20098 (2009), online at www.okgop.com/pdfs/PLATFORM2009 _APPROVED.PDF (visited Oct 22, 2011). 
state in public education" school curriculum and educational funding." In contrast with the national Democratic Party platforms that tend to avoid the issue, the Washington State Democratic Party platform of 2010 specifies opposition to "[o]rganized prayer in public schools."

To the extent that Presidents and their judicial appointment agendas reflect the processes and structures that frame American political life, one might expect to find that ideology influences federal judicial decisions involving religion and schools, at least at the margins. Indeed, this finding of an ideological influence on federal court decisions on religious liberty in the educational context from 1996 to 2005 is consistent with results from our earlier study. ${ }^{7 x}$ In our study of religious-liberty decisions in the federal courts from 1986 to 1995 , both traditional partisan and alternative ideology proxies were not statistically significant in any of our major models. ${ }^{79}$ The single exception was in the education context, where claims by parents and schoolchildren for accommodation of their religious beliefs or practices were more likely to be favorably received by Republican-appointed judges. As we concluded then, "This result is not surprising, given that conservatives in recent years have been most critical of the educational establishment and frequently bemoan the exclusion of religious influences from public educational institutions; likewise, conservatives have been protective of the rights of private schools to operate with minimal governmental oversight."

75 Colorado Democratic Party, Colorado Democratic Party Platform Process 2010-12: Platform Committee Report-v.6 Final 14 (2010), online at http://www.coloradodems.org/docs 2010PlatformWeb.pdf (visited Oct 22, 2011).

76 Minnesota Democratic-Farmer-Labor Party, Minnesota Democratic-Farmer-Labor Party Ongoing Platform 2 (2010), online at http://dfl.org/sites/dfl.org/files/2010\%20Ongoing \%20Platform.pdf (visited Oct 22, 2011).

77 Washington State Democrats, 2010 State Convention Platform: Plank 6; Education 2 (2010), online at http://www.wa-democrats.org/files/pdf/06\%20-\%20Education.pdf (visited Oct $22,2011)$.

78 See Sisk, Heise, and Morriss, 65 Ohio St L J at 602 (cited in note 26) (finding that judges who were appointed to the lower federal courts by Republican Presidents were significantly more likely to rule in favor of students or parents seeking a religious accommodation in public schools from 1986 to 1995).

79 See id (concluding that political ideology did not have a significant effect on the outcome of religious-liberty cases as a whole from 1986 to 1995 despite the evidence of a significant effect in the narrower set of cases involving religious accommodations for public school students).

80 Id. 
2. Common space scores.

As an alternative measure of judicial ideology, and to further test the robustness of a political or ideological influence in religiousliberty cases arising in public or private elementary and secondary education, we also coded each district and court of appeals judge for common space scores. Professors Keith Poole and Howard Rosenthal originally developed the "nominate common space" score measure of ideological preferences for members of Congress, placing all aspects of legislative voting into the same ideological dimension along a liberal-conservative continuum. ${ }^{81}$ Subsequently, Professors Michael Giles, Virginia Hettinger, and Todd Peppers adapted this measure for the study of judges:

Scores on this dimension are scaled from -1 for most liberal to +1 for most conservative. Absent senatorial courtesy the measure of senatorial preferences is assigned a value of zero [and the President's score is substituted]. If senatorial courtesy is operative and there are two senators of the President's party in a state, senatorial preferences are measured as the mean of the common space scores of the senators. ${ }^{12}$

Among political scientists, common space scores have come to be regarded as "the state-of-the-art measure for the preferences of US Court of Appeals judges." ${ }^{\prime \prime}$

Just as being appointed by a Republican President was positively associated with a proreligion vote on the religious-liberty claims in our study, being scored conservative on the common space score continuum was also positively associated with a proreligion vote. Holding all other variables constant at their means, the more liberal judges under the common space score measure (at -0.6 ) were predicted to cast a proreligion vote at a 26.6 percent rate, while the more conservative judges (at 0.6 ) were predicted to vote in a proreligion direction at a 63.7 percent rate.

In Figure 2, we generate the average predicted probabilities of a positive vote on an Establishment Clause claim for each common space score in the range from -0.6 to 0.6 , at increments of 0.1 , while

81 Keith T. Poole and Howard Rosenthal, Congress: A Political-Economic History of Roll Call Voting 23-26 (Oxford 1997).

82 Micheal W. Giles, Virginia A. Hettinger, and Todd Peppers, Picking Federal Judges: A Note on Policy and Partisan Selection Agendas, 54 Polit Rsrch Q 623, 631 (2001).

83 Lee Epstein, et al, The Judicial Common Space, 23 J L, Econ, \& Org 303, 306 (2007). For a more detailed discussion of common space scores as an ideology proxy, see Sisk and Heise, 110 Mich L Rev at *13 (cited in note 30 ). 
holding the other independent variables constant. The solid, darker line in the middle is the best estimate of the average predicted probability for that increment in the common space score. The lighter, broken lines that appear above and below are the higher and lower parameters of the 95 percent confidence intervals for the average predicted probability at each one-tenth increment of the common space score continuum.

Figure 2. Predicted PRobability of a PRoReligion Vote by JUDGE IN SCHOOL CASES, BY COMMON SPACE SCORE INCREMENTS

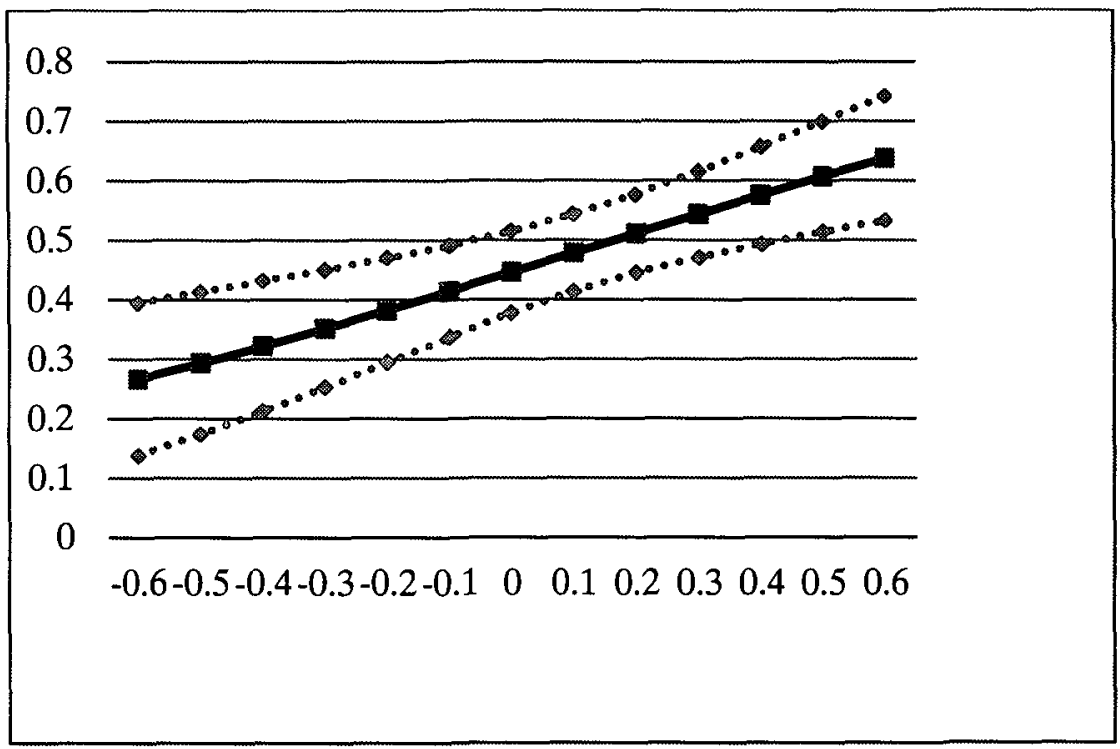

Note: Liberal $<0$; Conservative $>0$. Figure 2 draws from Table 3, column 2.

B. Judge Background and Community Demographic Variables

A federal judge's prior experience as a state or local judge was significantly and negatively correlated with the proreligion dependent variable in the context of school cases. Thus, prior service at the state or local level in the courts apparently was associated with a judge's propensity to rule against educational accommodations for religious adherents and against public educational policies acknowledging religion. The standard hypothesis has been that "the insulation from popular sentiments that the judicial office often provides" should make a judge with prior judicial experience "more 
willing to support potentially unpopular claims." However, when that prior experience was obtained at the state or local level, where judges often are subject to electoral approval, we previously have suggested that such judges may develop habits of greater deference to the products of the elected branches of government. ${ }^{85}$

In any event, the negative association by former state or local judges with the proreligion dependent variable in school cases does not fit comfortably into either interpretive package. While a vote to accept the claim of a religious believer seeking a Free Exercise Clause accommodation overturns the decisions of education officials and agencies, a vote to reject an Establishment Clause challenge to government interaction with religion affirms the actions of the government. Perhaps local and state judges, having seen the sometimes-volatile nature of religious disputes in their communities and local schools, become skeptical about the wisdom of any governmental interaction with or accommodation toward religion and religious believers.

Greater seniority of the judge (measured by number of months on the federal bench when the decision was issued) was also associated with a negative vote on the proreligion dependent variable. In prior research, the hypothesis has been that years of seniority on the bench "test hardening not of the biological arteries [as would age] but rather of the bureaucratic judicial arteries." our prior study of religious-liberty decisions from 1986 to 1995 , we found the seniority or time on the bench of the deciding judge to be significantly correlated with adoption of an antipolitical model for interpreting the religion clauses of the Constitution-that is, a tendency to overturn the decisions of the political branches of government. $^{87}$ In contrast, in this study of religious-liberty decisions from 1996 to 2005, the apparent adoption of a secularist perspective by judges of greater seniority involves a mix of rulings that sometimes defer to (in free exercise cases) and that sometimes demur to (in establishment clause cases) the actions or policies of government.

84 Jilda M. Aliotta, Combining Judges' Attributes and Case Characteristics: An Alternative Approach to Explaining Supreme Court Decisionmaking, 71 Judicature 277, 279 (1988) (speaking of Supreme Court justices with prior judicial experience).

85 Sisk, Heise, and Morriss, 65 Ohio St L J at 611 (cited in note 26).

86 Sheldon Goldman, Voting Behavior on the United States Courts of Appeals Revisited, 69 Am Polit Sci Rev 491, 499 (1975) (finding that judges who had spent more time on the federal court of appeals tended to arrive at decisions that would generally be considered more conservative than the decisions reached by their less experienced counterparts).

87 Sisk, Heise, and Morriss, 65 Ohio St L J at 516 (cited in note 26). 
In the end, this particular finding may be (at least in part) an artifact of our introduction of a control variable for establishment clause cases into this focused study of school cases. While that control variable serves a vital purpose in clarifying the separate and powerful effect of political variables on religious-liberty claims arising in the educational context, it may serve to distort the influence (or lack thereof) of such other variables as seniority. Indeed, when we remove the Establishment Clause control variable in alternative regression runs, seniority falls out of significance in one of the two models. Moreover, in our separate studies of Free Exercise Clause and Establishment Clause cases generally, seniority on the bench does not approach standard significance thresholds.

Finally, we note the finding that a higher Jewish presence in the population of the metropolitan area where the judge has his or her chambers was significantly associated with a proreligion ruling by the judge. Because Jews in the United States have "generally favored a policy of stringent separationism," we discuss elsewhere, ${ }^{89}$ we fear that our religious demographic variables may mask other underlying influences, based on population density or region of the country. Accordingly, without further exploration and recalibration of demographic variables, we are reluctant to place too much analytic weight on these specific findings.

\section{CONCLUSION}

In many ways, our finding that a judge's ideology influenced whether a judicial outcome in religion clauses cases involving elementary and secondary schools was proreligion does not surprise. This finding did not jar either of us, even though we both cling to the aspiration of impartial judging and view the rule of law as requiring something more than judicial policy preferences in disguise. Of course, to the extent that ideology is poised to emerge, it is hard to imagine a riper context than what we selected for study - schools.

We are also mindful that skeptics of a "legal" model of judging will find comfort and empirical support in the findings from this study. A few important factors should temper any firm conclusions drawn from these results, however. We begin by acknowledging that law is not perfectly determinate in every case, particularly in Establishment and Free Exercise Clause cases, that some level of

88 Michael J. Klarman, Rethinking the Civil Rights and Civil Liberties Revolutions, 82 Va L Rev 1, 58 (1996). See also Stephen M. Feldman, Religious Minorities and the First Amendment: The History, the Doctrine, and the Future, 6 U Pa J Const L 222, 238, 246 (2003).

89 Sisk and Heise, 110 Mich L Rev at *29 (cited in note 30 ). 
judicial discretion is both inevitable and, indeed, to some degree desirable, and that judges, as human beings, bring to their judicial decisions and analyses their general life experiences and perspectives to the task. Indeed, current Supreme Court religion clauses jurisprudence almost guarantees as much. By failing to more clearly define its reasoning in majority opinions, by emphasizing a multiplicity of theoretical approaches that resist distillation into a single, coherent theme owing to uncertainties about discerning the governing legal rules and doctrine, and by offering the vaguest generalities in articulating adjudication standards, the Supreme Court's religion clauses rulings all but ask even the most conscientious of lower court judges to draw on personal reactions to religion and political attitudes about the role of religion in leading public institutions, including schools.

Compounding problems for lower federal court judges posed by legal uncertainty, the education context, particularly elementary and secondary schooling, is especially loaded from a political and ideological standpoint. Indeed, precious few issues can be more highly charged and politically sensitive than religious issues incident to the operation of schools for the nation's youth. The school endures as a unique institution in the manner in which it brings together the public and private lives of citizens. It is also the locus of a collision of rights and interests between and among students, their parents, teachers, administrators, and citizens. Thus, either factorlegal uncertainty or a highly charged political context-would lead many to expect that the judge's ideology will inform legal analyses. That these two factors interact in our context all but assures that ideology will play some role. Indeed, given our focus on religious cases involving schools, we would have been far more surprised not to find evidence of ideology influencing judicial outcomes in some way.

Results such as ours, flowing from a specific context involving one particular corner (albeit, an important one) of constitutional law, benefit from greater context. Existing empirical evidence drawn from the larger landscape of judging in the federal lower courts provides little by way of empirical support for the conclusion that judicial ideology or a purely attitudinal model of judicial decision making has displaced the legal model. Specifically, the weight of existing evidence drawn from studies exploring large numbers of judicial outcomes across a diverse array of subject matter and fields 
suggests that extralegal factors, including a judge's ideology, explain only a small part of the variation in judicial outcomes."

In the future, researchers might consider extending our analysis in various ways. For example, other discrete settings (that is, settings besides school) would benefit from similar analyses to test whether our findings are unique to the setting or, in contrast, are robust in religion cases across various settings. Aside from whether alternative contexts are studied, researchers might also consider the admittedly arduous task of gathering and coding the larger set of unpublished and undigested decisions. Although we do not feel that the inclusion of unpublished decisions would materially upset our major findings, similar analyses in different contexts strike us as a quite promising and interesting avenue for future work. We are as curious as anyone else about whether the salience of ideology that we find in the school context would emerge in religion clauses decisions involving other contexts.

Insofar as the push for education reform is unlikely to dissipate anytime soon, the number and magnitude of intersections involving religion and schooling will continue to increase and place increased stress on legal doctrines. Thus, however one receives evidence of ideology influencing judicial outcomes in religion clauses cases involving schools, it is likely that this evidence will persist over time.

90 See Frank B. Cross, Decision Making in the U.S. Courts of Appeals 38 (Stanford 2007); Jason J. Czarnezki and William K. Ford, The Phantom Philosophy? An Empirical Investigation of Legal Interpretation, $65 \mathrm{Md}$ L Rev 841, 882-84 (2006); Sisk and Heise, $99 \mathrm{Nw}$ U L Rev at 746 (cited in note 30); Gregory C. Sisk, The Quantitative Moment and the Qualitative Opportunity: Legal Studies of Judicial Decision Making, 93 Cornell L Rev 873, 877 (2008). 